\title{
Mutation analysis of the genes linked to early onset Alzheimer's disease and frontotemporal lobar degeneration
}

Laura Luukkainen $^{\mathrm{a}, \mathrm{b}}$, Seppo Helisalmi ${ }^{\mathrm{c}}$, Laura Kytövuori ${ }^{\mathrm{a}, \mathrm{b}}$, Riitta Ahmasalo ${ }^{\mathrm{d}}$, Eino Solje ${ }^{\mathrm{c}, \mathrm{e}}$, Annakaisa Haapasalo ${ }^{\mathrm{f}}$, Mikko Hiltunen ${ }^{\mathrm{g}}$, Anne M Remes ${ }^{\mathrm{a}, \mathrm{b}}$, Johanna Krüger ${ }^{\mathrm{a}, \mathrm{b}}$

Affiliations:

${ }^{a}$ Research Unit of Clinical Neuroscience, Neurology, University of Oulu, Oulu, Finland

${ }^{\mathrm{b}}$ MRC, Oulu University Hospital, Oulu, Finland

${ }^{\mathrm{c}}$ Institute of Clinical Medicine, Neurology, University of Eastern Finland, Kuopio, Finland

${ }^{\mathrm{d}}$ Department of Neurology, Lapland Central Hospital, Rovaniemi, Finland

${ }^{\mathrm{e}}$ Neuro Center, Neurology, Kuopio University Hospital, Kuopio, Finland

${ }_{\mathrm{f}}^{\mathrm{A}}$.I. Virtanen Institute for Molecular Sciences, University of Eastern Finland

${ }^{\mathrm{g}}$ Institute of Biomedicine, University of Eastern Finland, Kuopio, Finland

Corresponding author:

Anne Remes

$\mathrm{MD}, \mathrm{PhD}$, Professor, Dean

Faculty of Medicine, University of Oulu

Aapistie 5 A, FIN-90230 Oulu, Finland

anne.remes@oulu.fi, tel: +358 505330090

Running title: Mutation analysis in early onset AD and FTLD 


\section{Abstract}

A lot of efforts have been done to unravel the genetics underlying early-onset Alzheimer's disease (AD) and frontotemporal lobar degeneration (FTLD). However, still many familial early-onset dementia (EOD) cases show an unclear genetic background. The aim of this study was to evaluate the role of the known causative mutations and possible pathogenic variants associated with AD and FTLD in a Finnish EOD cohort. The cohort consisted of 39 patients (mean age at onset 54.8 years, range $39-65$ ) with a positive family history of dementia or an atypical or rapidly progressive course of the disease. None of the patients carried the $C 9$ orf 72 hexanucleotide repeat expansion. Mutations and variants in APP, PSEN1, PSEN2, MAPT, GRN, VCP, CHMP2B, FUS, TARDBP, TREM2, TMEM106B, UBQLN2, SOD1, PRNP, UBQLN1 and BIN1 were screened by using a targeted next generation sequencing (NGS) panel. Two previously reported pathogenic mutations (PSEN1 p.His163Arg and MAPT p.Arg406Trp) were identified in the cohort. Both patients had familial dementia with an atypical early onset phenotype. In addition, a heterozygous p.Arg71Trp mutation in PSEN2 with an uncertain pathogenic nature was identified in a patient with neuropathologically confirmed AD. In conclusion, targeted investigation of the known dementia-linked genes is worthwhile in patients with onset age under 55 and a positive family history, as well as in patients with atypical features.

Key words: Alzheimer's disease, frontotemporal lobar degeneration, frontotemporal dementia, genetics, early onset, presenilin-1, mutation, missense, microtubule-associated protein tau, human. 


\section{Introduction}

Alzheimer's disease (AD) and frontotemporal lobar degeneration (FTLD) are the two most common causes for early-onset dementia (EOD) [1]. Approximately 35-60\% of the early-onset $\mathrm{AD}(\mathrm{EOAD})$ and over $40 \%$ of the FTLD patients have at least one affected first-degree relative in their family and approximately $10 \%$ of these patients present the pattern of autosomal dominant inheritance $[2,3]$. The patient's probability of having AD caused by a pathogenic mutation increases if the his or her family presents $\mathrm{AD}$ in several generations and the age at the onset is very early (under 55 years) [4]. Mutations in amyloid precursor protein (APP), presenilin-1 (PSEN1) and presenilin-2 (PSEN2) genes account for 5-10\% of EOAD while at least $20 \%$ of the EOAD patients have been estimated to display autosomal dominant inheritance of a still unknown genetic background [2]. To date, over 50 pathogenic mutations in APP, over 200 mutations in PSEN1 and over 30 mutations in PSEN2 genes are known to cause EOAD [2]. The $C 9$ orf72 hexanucleotide repeat expansion or $M A P T$ and $G R N$ mutations underlie the majority of the familial FTLD [5,6]. In Finland, the prevalence of the $C 9$ orf72 repeat expansion is exceptionally high [7], whereas MAPT and GRN mutations associated with FTLD or PSEN1, PSEN2 and APP mutations associated with AD have been found to be very rare [8-10].

The apolipoprotein $\mathrm{E}(A P O E 4) \varepsilon 4$ allele is the main genetic risk factor for both EOAD and late onset AD (LOAD)[2]. However, APOE4 has not been indicated to elevate the risk for FTLD. Recent genome-wide association studies (GWAS) and next generation sequencing studies (NGS) have so far identified over 20 other AD risk genes and genetic loci [11]. The genetic risk factors identified for LOAD have been suggested to modulate the risk for EOAD as well $[12,13]$. Previous NGS studies have shown that EOD patients are more often associated with multiple rare variants or risk alleles than LOAD patients or healthy controls [12]. 
The aim of this study was to evaluate the genetic background of a Finnish EOD cohort by analysing genes associated with $\mathrm{AD}$ and FTLD using targeted next generation exome sequencing.

\section{Patients and methods}

The study population consisted of 39 patients with EOD diagnosed at two memory outpatient clinics in Finland (Oulu University and Kuopio University Hospitals). The inclusion criteria of the patients were 1) early onset of the disorder (before 65 years) and 2) at least one patient with dementia in their family or 3) atypical or rapidly progressive course of the disease. All the patients were examined and diagnosed by an experienced neurologist specialized in memory disorders. The diagnoses were made according to the current prevailing diagnostic criteria for each disease. Also re-evaluation of the diagnoses [14-17] for this study was made by experienced neurologists. In total, 29 patients were diagnosed with $\mathrm{AD}$, nine with FTLD and one with progressive supranuclear paresis. Three of the FTLD patients had also motor neuron disease. In our cohort, $44 \%(n=17)$ patients had at least one first-degree relative with dementia or cognitive decline and $51 \%(n=20)$ patients had a family history of cognitive decline in at least in second-degree relatives.

The mean age at onset was 54.8 years (range 39-65) and the mean age at diagnosis was 57.6 years (range 40-67). The patients carrying the $C 9$ orf72 repeat expansion were excluded from the study. Three patients were carriers of the APOE4 allele and they all had APOE genotype E3/E4. The study was performed according to the principles of the Declaration of Helsinki. Written informed consent was obtained from all the patients or their caregivers. The research protocol was approved by the ethic committees of the Northern Ostrobothnia hospital district and by the Northern Savo hospital district. 
DNA was extracted from the blood samples by standard methods. DNA purification was done with Qiagen purification Kit (Qiagen, Hilden, Germany) according to the original protocol. The repeat-primed polymerase chain reaction assay (RP-PCR) was used to indicate the presence or absence of the $C 9$ orf 72 repeat expansion [18]. Targeted gene exon libraries were prepared using NimbleGen SeqCap EZ Library kit (Roche, Basel, Switzerland) with customized SeqCap EZ Neurology Panel Design (Roche, Basel, Switzerland), covering all exons and exon-intron boundaries of 258 genes associated with 87 neurological diseases and disorders (Supplementary table 1). Furthermore, 22 additional genes were included in the panel (Supplementary table 2). Samples were sequenced using Illumina MiSeq sequencer (Illumina, San Diego, USA, CA).

Based on previous genetic findings of AD and FTLD, 16 genes (APP, PSEN1, PSEN2, MAPT, GRN, VCP, CHMP2B, FUS, TARDBP, TREM2, TMEM106B, UBQLN2, SOD1, UBQLN1, PRNP and BIN1) were selected for detailed investigation from the targeted panel of 258 genes and 22 additional genes. An in-house developed analysis pipeline was used for the evaluation of raw fastq files generated by the MiSeq sequencer. The data was manually screened to find exonic single-nucleotide mutations that cause a protein change. The recognized mutations were categorized as pathogenic, non-pathogenic and possible new variants or risk variants according to the previous literature and databases [19]. The relevant findings were confirmed by Sanger sequencing with ABI3500xL Genetic Analyzer (Applied Biosystems Inc, Foster City, USA, California). Primers and reaction conditions are available upon request. Exon-intron boundaries of APP, PSEN1, PSEN2, MAPT, GRN, VCP, CHMP2B, FUS and TARDBP genes were manually screened to find splice site mutations.

\section{Results}


Two patients (5.1\%) were found to harbor previously reported pathogenic mutations p.His163Arg in PSEN1 or p.Arg406Trp in MAPT. In addition, a PSEN2 p.Arg71Trp mutation with an unclear pathogenic nature [20] was detected in a neuropathologically confirmed AD patient.

We also identified non-pathogenic variants GRN p.Arg433Trp, PSEN1 p.Glu318Gly, MAPT p.GIn230Arg and MAPT p.Tyr441His in our cohort. Furthermore, we detected three AD risk variants in TREM2, UBQLN2 and BIN1 genes. Two variants in TMEM106B gene which have previously been reported to be associated with mainly FTD were detected in both AD and FTLD patients (Table 1). Moreover, we found one intronic splice-site mutation in APP which has unknown effect on protein code (Table 1.). All the patients were heterozygous carriers of the mutations or variants. The patient carrying the TREM2 variant had APOE genotype E3/E4.

Phenotypes of the patients carrying the pathogenic mutations

PSEN1 p.His163Arg (c.A488G)

A 39-year-old woman referred to a neurologist due to rapidly progressive cognitive decline. A bipolar mood disorder had been diagnosed in her early twenties. In neurological examination, the patient presented slight postural tremor in her upper limbs, clumsy movements and myoclonic jerks. In addition, tardive dyskinesia/tic-symptoms were observed around her mouth as well as vocal tics. The patient was euphoric, and she presented behavioral disinhibition. Magnetic resonance imaging (MRI) of the brain was normal. In the cerebrospinal fluid (CSF) examination, phosphorylated tau was elevated, $252 \mathrm{pg} / \mathrm{ml}$ (normal concentration under 70 $\mathrm{pg} / \mathrm{ml}$ ), while beta-amyloid-42 $\left(\mathrm{A} \beta_{42}\right)$ was relatively low, $582 \mathrm{pg} / \mathrm{ml}$ (normal concentration over $500 \mathrm{pg} / \mathrm{ml})$. Neuropsychological examination revealed severe cognitive decline and the patient was diagnosed to have AD. At the age of 44 years she had an epileptic seizure and a computed 
tomography (CT) of the brain was done showing severe central atrophy and Scheltens grade 2 hippocampal atrophy [21]. Slowness and central spikes, but no epileptic bursts were found in the electroencephalography. At the age of 45 years she was bedridden and unable to speak. The patient died at the age of 46 years, but no autopsy was done. Her mother and sister as well as many of the mother's siblings had been diagnosed with psychiatric syndromes. The patient's mother had also Parkinson's disease and she had died at the age of 70 years.

\section{MAPT p.Arg406Trp (c.C1216T)}

A 52-year-old woman presented subjective memory disturbances. In addition, her behaviour was impulsive and she had fluctuating mood changes. Neuropsychological examination revealed mild problems in concentration and her performance was slow, however at that point the neuropsychological profile was not regarded supportive for a dementing disease. At the age of 55 years, she was again referred to neurologist because of increasing memory problems. Neuropsychological examination revealed a decline in episodic memory, time orientation, visual reasoning, and perception in addition to executive dysfunction. She also suffered from depression and psychosis. In neurological examination, she had intention tremor and her speech was uninhibited but otherwise the examination was normal. Brain MRI showed moderate hippocampal atrophy bilaterally and cortical atrophy especially in the temporobasal areas. The CSF biomarkers for AD were normal. The patient was diagnosed to have frontal variant of AD. Four years after the diagnosis, the neuropsychological examination revealed severe cognitive decline, especially memory impairment, including major problems in delayed recall, working memory, learning and verbal memory in addition to executive dysfunction. The patient's mother got demented in her early fifties and her sister had been diagnosed to have AD at the age of 52 years. The patient also carried the UBQLN2 p. Ile501Thr variant. 
PSEN2 p.Arg71Trp (c.C211T)

A 55-year-old male referred to neurologist due to memory problems. Brain MRI indicated a Dandy-Walker malformation. In a follow-up, gradual cognitive decline and increasing memory problems were noticed and he was clinically diagnosed to have AD. At the age of 59 years, he indicated to have normal pressure hydrocephalus and a brain biopsy was obtained during the shunt operation. The histology of the brain biopsy showed typical neuropathological findings for $\mathrm{AD}$, including considerable amount of beta-amyloid plaques but no amyloid pathology in the vessels. The accumulation of tau was detected as tangles, plaques, and cytoplasmic inclusions. There were also p62-positive cytoplasmic inclusions, tangles and fibrils, and a few TDP-43-positive cytoplasmic inclusions.

\section{Discussion}

In the present study, we have aimed at elucidating the genetic background of early-onset AD and FTLD cases. We found two previously reported pathogenic mutations in our cohort of EOD. The onset of the disease was under 55 years and both patients had a positive family history of neurodegenerative diseases. The PSEN1 p.His163Arg mutation has been found in over 20 families worldwide so far [19]. PSEN1 mutations have commonly been associated with very early-onset $\mathrm{AD}$ with atypical clinical features [22,23]. Interestingly, the location of the PSEN1 mutation appears to lead to differences in clinical manifestations. Patients with mutations before codon 200, such as the PSEN1 p.His163Arg mutation, usually show an early onset of the disease and more frequently display generalized seizures and myoclonus, all of which were also present in the patient of our study [24]. Interestingly, the patient also suffered from vocal tics. A few previously reported PSEN1 p.His163Arg mutation carriers have also had 
visual hallucinations and parkinsonism with rigidity and bradykinesia, but these symptoms were not observed in our patient [25]. However, the fact that the mother of the PSEN1 p.His163Arg mutation carrier had manifested parkinsonism and psychiatric symptoms suggests that she might have been a PSEN1 p.His163Arg mutation carrier as well.

The MAPT p.Arg406Trp mutation has been reported in over 60 patients so far [26]. Mutations in the MAPT gene are typically associated with tau pathology [26]. Despite the neuropathological findings typical for FTLD, the clinical phenotypes of the patients with the MAPT p.Arg406Trp mutation have suggested that they rather have AD than FTLD [26]. Especially, amnestic cognitive decline has been the most frequent first symptom in patients carrying this mutation, leading to AD diagnosis in the majority of the cases [26]. This phenotype was also present in the patient of our study. In addition to cognitive decline, the patient suffered from behavioural problems and severe psychiatric symptoms. A few MAPT p.Arg406Trp mutation carriers have also shown parkinsonian symptoms, but these were not detected in our patient [27]. About half of the previously reported mutation carriers have had elevated levels of tau and phosphorylated tau in the CSF. However, in our patient, the CSF AD biomarkers were normal [26]. In previous cases, the median age at onset has been 55 years, which is in line with our case [26].

We also detected a PSEN2 p.Arg71Trp mutation, the pathogenicity of which is unclear [20]. This mutation has been found both in late-onset AD (LOAD) and EOAD patients [28-31]. However, the facts that it did not appear to segregate with $\mathrm{AD}$ in the families of the carriers, nor did it affect the $A \beta 42 / A \beta 40$ ratio in an in vitro assay, and it was also found in healthy controls suggest that it is likely a benign mutation $[10,20,28]$. Interestingly though, the brain biopsy of the patient in our study revealed AD-type neuropathology. There is also a previous report of severe AD-type neuropathological findings of one PSEN2 p.Arg71Trp mutation carrier, who had an early onset, but very slowly progressive AD [31]. Patients carrying the 
PSEN2 mutations have usually an onset of the disease around 60 years and the disease duration may be even 20 years further suggesting that this mutation associates with slow disease progression [24]. Allele frequency of the PSEN2 p.Arg71Trp in the Finnish population is low $(0.0195 \%$, Table 1). However, since it has been found also in Finnish healthy controls, it has been suggested that alone this mutation is not likely sufficient to cause AD [10]. Nevertheless, PSEN2 p.Arg71Trp mutation might be a risk factor for AD or possibly even pathogenic with a slowly progressive course of the disease regarding that the frequency of the mutation has been reported to be higher in LOAD patients than in the general population [32] and it is possible that some of the healthy controls in the previous studies that were found to carry the PSEN2 p.Arg71Trp mutation might have developed AD later.

We also identified GRN p.Arg433Trp, PSEN1 p.Glu318Gly, MAPT p.Gln230Arg, and MAPT p.Tyr441His variants that have been suggested to be benign in previous studies [19]. PSEN1 p.Glu318Gly might be a risk factor for familial AD, but the results so far are controversial [33]. Furthermore, we identified three variants, which have previously been described as possible risk variants for AD or FTLD and one variant with possible risk-reducing effect (Table 1). The carrier of the TREM2 p.Arg62His variant had also APOE genotype E3/E4. TREM2 p.Arg62His has been reported as a possible risk factor for LOAD (OR 0.8-2.3) [34] and it has also been found in a few EOAD cases [12]. The interaction of the APOE4 allele and TREM2 has been suggested to accelerate the development of neurodegeneration [35]. The effects of the other identified possible risk variants have been less significant [36-39]. The frequencies of these polymorphisms in our cohort did not differ from the population frequencies reported in the ExAC database. In any case, our cohort was too small to make any conclusions regarding the involvement of these variants in influencing the risk for dementia.

The key role of the C9orf72 repeat expansion has been well demonstrated in FTLD and its prevalence is high in Finland [5-7]. In this study we focused on to search for other pathogenic 
mutations and risk factors for AD and FTLD in the cohort of EOD patients of still unknown genetic background after exclusion of the $C 9$ orf 72 repeat expansion. The strength of this study is that our cohort is clinically very well-characterized, and the patients have been thoroughly examined by experienced neurologists specialized in memory disorders, increasing the validity of our results.

In conclusion, we identified two pathogenic mutations in PSEN1 and MAPT genes in a Finnish EOD cohort. Both identified cases had a very early onset of the disease and a positive family history of dementia or psychiatric diseases. Even though autosomal dominant mutations are rare causes of dementia, our study suggests that it is worthwhile to screen for them in EOD patients, who show an onset age under 55 years and a positive family history.

\section{Acknowledgements}

We thank the participating patients and MS Anja Heikkinen and MS Sari Pyrhönen for their excellent technical assistance.

\section{Funding sources}

This study was supported by brain research grant from University of Oulu (LL, AMR), the Finnish Brain Foundation (ES), Academy of Finland (no 307866, MH; no 315459, AH; no 315460, AMR), and Sigrid Jusélius Foundation (MH), and the Strategic Neuroscience Funding of the University of Eastern Finland (MH; $\mathrm{AH})$.

\section{Conflict of Interest/Disclosure Statement}

The authors have no conflict of interest to report. 


\section{References}

[1] Vieira RT, Caixeta L, Machado S, Silva AC, Nardi AE, Arias-Carrión O, Carta MG (2013) Epidemiology of early-onset dementia: a review of the literature. Clin. Pract. Epidemiol. Ment. Health 9, 88-95.

[2] Cacace R, Sleegers K, Van Broeckhoven C (2016) Molecular genetics of early-onset Alzheimer's disease revisited. Alzheimer's Dement. 12, 733-748.

[3] Bang J, Spina S, Miller BL (2015) Frontotemporal dementia. Lancet 386, 1672-1682.

[4] Loy CT, Schofield PR, Turner AM, Kwok JBJ (2014) Genetics of dementia. Lancet 383, 828-840.

[5] Mahoney CJ, Beck J, Rohrer JD, Lashley T, Mok K, Shakespeare T, Yeatman T, Warrington EK, Schott JM, Fox NC, Rossor MN, Hardy J, Collinge J, Revesz T, Mead S, Warren JD (2012) Frontotemporal dementia with the C9ORF72 hexanucleotide repeat expansion: Clinical, neuroanatomical and neuropathological features. Brain $\mathbf{1 3 5}$, 736-750.

[6] Rohrer JD, Guerreiro R, Vandrovcova J, Uphill J, Reiman D, Beck J, Isaacs AM, Authier A, Ferrari R, Fox NC, Mackenzie IRA, Warren JD, de Silva R, Holton J, Revesz T, Hardy J, Mead S, Rossor MN (2009) The heritability and genetics of frontotemporal lobar degeneration. Neurology 73, 1451-1456.

[7] Majounie E, Renton AE, Mok K, Dopper EGP, Waite A, Rollinson S, Chiò A, Restagno G, Nicolaou N, Simon-Sanchez J, van Swieten JC, Abramzon Y, Johnson JO, Sendtner M, Pamphlett R, Orrell RW, Mead S, Sidle KC, Houlden H, Rohrer JD, Morrison KE, Pall H, Talbot K, Ansorge O, Hernandez DG, Arepalli S, Sabatelli M, Mora G, Corbo M, Giannini F, Calvo A, Englund E, Borghero G, Floris GL, Remes AM, Laaksovirta H, McCluskey L, Trojanowski JQ, Van Deerlin VM, Schellenberg 
GD, Nalls MA, Drory VE, Lu CS, Yeh TH, Ishiura H, Takahashi Y, Tsuji S, Le Ber I, Brice A, Drepper C, Williams N, Kirby J, Shaw P, Hardy J, Tienari PJ, Heutink P, Morris HR, Pickering-Brown S, Traynor BJ (2012) Frequency of the C9orf72 hexanucleotide repeat expansion in patients with amyotrophic lateral sclerosis and frontotemporal dementia: A cross-sectional study. Lancet Neurol11, 323-330.

[8] Kaivorinne AL, Krüger J, Kuivaniemi K, Tuominen H, Moilanen V, Majamaa K, Remes AM (2008) Role of MAPT mutations and haplotype in frontotemporal lobar degeneration in Northern Finland. BMC Neurol 8, 48.

[9] Krüger J, Kaivorinne AL, Udd B, Majamaa K, Remes AM (2009) Low prevalence of progranulin mutations in Finnish patients with frontotemporal lobar degeneration. Eur. J. Neurol 16, 27-30

[10] Krüger J, Moilanen V, Majamaa K, Remes AM (2012) Molecular genetic analysis of the APP, PSEN1, and PSEN2 genes in finnish patients with early-onset alzheimer disease and frontotemporal lobar degeneration. Alzheimer Dis. Assoc. Disord 26, 272276.

[11] Cuyvers E, Sleegers K (2016) Genetic variations underlying Alzheimer's disease: Evidence from genome-wide association studies and beyond. Lancet Neurol. 15, 857868.

[12] Bonvicini C, Scassellati C, Benussi L, Di Maria E, Maj C, Ciani M, Fostinelli S, Mega A, Bocchetta M, Lanzi G, Giacopuzzi E, Ferraboli S, Pievani M, Fedi V, Defanti CA, Giliani S, Frisoni GB, Ghidoni R, Gennarelli M (2019) Next Generation Sequencing Analysis in Early Onset Dementia Patients. J. Alzheimer's Dis. 67, 243-256.

[13] Piccoli E, Rossi G, Rossi T, Pelliccioni G, D’Amato I, Tagliavini F, Di Fede G (2016) Novel PSEN1 mutations (H214N and R220P) associated with familial Alzheimer's 
disease identified by targeted exome sequencing. Neurobiol. Aging 40, 192.e7-192.e11.

[14] McKhann G, Knopman DS, Chertkow H, Hymann B, Jack CR, Kawas C, Klunk W, Koroshetz W, Manly J, Mayeux R, Mohs R, Morris J, Rossor M, Scheltens P, Carrillo M, Weintrub S, Phelphs C (2011) The diagnosis of dementia due to Alzheimer's disease: Recommendations from the National Institute on Aging- Alzheimer's Association workgroups on diagnostic guidelines for Alzheimer's disease. Alzheimers Dement. 7, 263-269.

[15] Rascovsky K, Hodges JR, Knopman D, Mendez MF, Kramer JH, Neuhaus J, Van Swieten JC, Seelaar H, Dopper EGP, Onyike CU, Hillis AE, Josephs KA, Boeve BF, Kertesz A, Seeley WW, Rankin KP, Johnson JK, Gorno-Tempini ML, Rosen H, Prioleau-Latham CE, Lee A, Kipps CM, Lillo P, Piguet O, Rohrer JD, Rossor MN, Warren JD, Fox NC, Galasko D, Salmon DP, Black SE, Mesulam M, Weintraub S, Dickerson BC, Diehl-Schmid J, Pasquier F, Deramecourt V, Lebert F, Pijnenburg Y, Chow TW, Manes F, Grafman J, Cappa SF, Freedman M, Grossman M, Miller BL (2011) Sensitivity of revised diagnostic criteria for the behavioural variant of frontotemporal dementia. Brain 134, 2456-2477.

[16] Gorno-Tempini ML, Hillis AE, Weintraub S, Kertesz A, Mendez M, Cappa SF, Ogar JM, Rohrer JD, Black S, Boeve BF, Manes F, Dronkers NF, Vandenberghe R, Rascovsky K, Patterson K, Miller BL, Knopman DS, Hodges JR, Mesulam MM, Grossman M (2011) Classification of primary progressive aphasia and its variants. Neurology 76, 1006-1014.

[17] Litvan I, Agid Y, Calne D, Campbell G, Dubois B, Duvoisin RC, Goetz CG, Golbe LI, Grafman J, Growdon JH, Hallett M, Jankovic J, Quinn NP, Tolosa E, Zee DS (1996) Clinical research criteria for the diagnosis of progressive supranuclear palsy (Steele- 
Richardson-Olszewski syndrome): Report of the NINDS-SPSP International Workshop. Neurology 47, 1-9.

[18] Renton AE, Majounie E, Waite A, Simón-Sánchez J, Rollinson S, Gibbs JR, Schymick JC, Laaksovirta H, van Swieten JC, Myllykangas L, Kalimo H, Paetau A, Abramzon Y, Remes AM, Kaganovich A, Scholz SW, Duckworth J, Ding J, Harmer DW, Hernandez DG, Johnson JO, Mok K, Ryten M, Trabzuni D, Guerreiro RJ, Orrell RW, Neal J, Murray A, Pearson J, Jansen IE, Sondervan D, Seelaar H, Blake D, Young K, Halliwell N, Callister JB, Toulson G, Richardson A, Gerhard A, Snowden J, Mann D, Neary D, Nalls MA, Peuralinna T, Jansson L, Isoviita VM, Kaivorinne AL, Hölttä-Vuori M, Ikonen E, Sulkava R, Benatar M, Wuu J, Chiò A, Restagno G, Borghero G, Sabatelli M, Heckerman D, Rogaeva E, Zinman L, Rothstein JD, Sendtner M, Drepper C, Eichler EE, Alkan C, Abdullaev Z, Pack SD, Dutra A, Pak E, Hardy J, Singleton A, Williams NM, Heutink P, Pickering-Brown S, Morris HR, Tienari PJ, Traynor BJ (2011) A hexanucleotide repeat expansion in C9ORF72 is the cause of chromosome 9p21-linked ALS-FTD. Neuron 72, 257-268.

[19] Cruts M, Theuns J, Van Broeckhoven C (2012) Locus-specific mutation databases for neurodegenerative brain diseases. Hum. Mutat 33, 1340-1344.

[20] Lanoiselée HM, Nicolas G, Wallon D, Rovelet-Lecrux A, Lacour M, Rousseau S, Richard AC, Pasquier F, Rollin-Sillaire A, Martinaud O, Quillard-Muraine M, de la Sayette V, Boutoleau-Bretonniere C, Etcharry-Bouyx F, Chauviré V, Sarazin M, le Ber I, Epelbaum S, Jonveaux T, Rouaud O, Ceccaldi M, Félician O, Godefroy O, Formaglio M, Croisile B, Auriacombe S, Chamard L, Vincent JL, Sauvée M, MarelliTosi C, Gabelle A, Ozsancak C, Pariente J, Paquet C, Hannequin D, Campion D (2017) APP, PSEN1, and PSEN2 mutations in early-onset Alzheimer disease: A genetic screening study of familial and sporadic cases. PLoS Med. 14, 1-16. 
[21] Scheltens P, Launer LJ, Barkhof F, Weinstein HC, van Gool WA (1995) Visual assessment of medial temporal lobe atrophy on magnetic resonance imaging: Interobserver reliability. J. Neurol 242, 557-560.

[22] Gómez-Tortosa E, Barquero S, Barón M, Gil-Neciga E, Castellanos F, Zurdo M, Manzano S, Muoz DG, Jiménez-Huete A, Rábano A, Sainz MJ, Guerrero R, Gobernado I, Pérez-Pérez J, Jiménez-Escrig A (2010) Clinical-genetic correlations in familial Alzheimer's disease caused by presenilin 1 mutations. J. Alzheimer's Dis 19, 873-884.

[23] Yagi R, Miyamoto R, Morino H, Izumi Y, Kuramochi M, Kurashige T, Maruyama H, Mizuno N, Kurihara H, Kawakami H (2014) Detecting gene mutations in Japanese Alzheimer's patients by semiconductor sequencing. Neurobiol. Aging 35, 1780.e11780.e5.

[24] Shea YF, Chu LW, Chan AOK, Ha J, Li Y, Song YQ (2016) A systematic review of familial Alzheimer's disease: Differences in presentation of clinical features among three mutated genes and potential ethnic differences. J. Formos. Med. Assoc 115, 6775.

[25] Lohmann E, Guerreiro RJ, Erginel-Unaltuna N, Gurunlian N, Bilgic B, Gurvit H, Hanagasi HA, Luu N, Emre M, Singleton A (2012) Identification of PSEN1 and PSEN2 gene mutations and variants in Turkish dementia patients. Neurobiol. Aging 33, 1850.e17-27.

[26] Ygland E, Van Westen D, Englund E, Rademakers R, Wszolek ZK, Nilsson K, Nilsson C, Landqvist Waldö M, Alafuzoff I, Hansson O, Gustafson L, Puschmann A (2018) Slowly progressive dementia caused by MAPT R406W mutations: Longitudinal report on a new kindred and systematic review. Alzheimer's Res. Ther 10. 
[27] Carney RM, Kohli MA, Kunkle BW, Naj AC, Gilbert JR, Züchner S, Pericak-Vance MA (2014) Parkinsonism and distinct dementia patterns in a family with the MAPT R406W mutation. Alzheimer's Dement 10, 360-365.

[28] Sleegers K, Roks G, Theuns J, Aulchenko YS, Rademakers R, Cruts M, Van Gool WA, Van Broeckhoven C, Heutink P, Oostra BA, Van Swieten JC, Van Duijn CM (2004) Familial clustering and genetic risk for dementia in a genetically isolated Dutch population. Brain 127, 1641-1649.

[29] Guerreiro RJ, Baquero M, Blesa R, Boada M, Brás JM, Bullido MJ, Calado A, Crook R, Ferreira C, Frank A, Gómez-Isla T, Hernández I, Lleó A, Machado A, MartínezLage P, Masdeu J, Molina-Porcel L, Molinuevo JL, Pastor P, Pérez-Tur J, Relvas R, Oliveira CR, Ribeiro MH, Rogaeva E, Sa A, Samaranch L, Sánchez-Valle R, Santana I, Tàrraga L, Valdivieso F, Singleton A, Hardy J, Clarimón J (2010) Genetic screening of Alzheimer's disease genes in Iberian and African samples yields novel mutations in presenilins and APP. Neurobiol. Aging 31, 725-731.

[30] Nicolas G, Wallon D, Charbonnier C, Quenez O, Rousseau S, Richard AC, RoveletLecrux A, Coutant S, Le Guennec K, Bacq D, Garnier JG, Olaso R, Boland A, Meyer V, Deleuze JF, Munter HM, Bourque G, Auld D, Montpetit A, Lathrop M, GuyantMaréchal L, Martinaud O, Pariente J, Rollin-Sillaire A, Pasquier F, Le Ber I, Sarazin M, Croisile B, Boutoleau-Bretonnire C, Thomas-Antérion C, Paquet C, Sauvée M, Moreaud O, Gabelle A, Sellal F, Ceccaldi M, Chamard L, Blanc F, Frebourg T, Campion D, Hannequin D (2016) Screening of dementia genes by whole-exome sequencing in early-onset Alzheimer disease: Input and lessons. Eur. J. Hum. Genet. $24,710-716$.

[31] Neurol JNE (2016) American Association of Neuropathologists, Inc. Abstracts of the 
92nd Annual Meeting June 16-19, 2016 Baltimore, MD. J. Neuropathol. Exp. Neurol 75, 567-616.

[32] Cruchaga C, Chakraverty S, Mayo K, Vallania FLM, Mitra RD, Faber K, Williamson J, Bird T, Diaz-Arrastia R, Foroud TM, Boeve BF, Graff-Radford NR, St. Jean P, Lawson M, Ehm MG, Mayeux R, Goate AM, for the NIA-LOAD - NCRAD Family Study Consortium (2012) Rare variants in APP, PSEN1 and PSEN2 increase risk for AD in late-onset Alzheimer's disease families. PLoS One 7, 1-10.

[33] Abdala BB, dos Santos JM, Gonçalves AP, da Motta LB, Laks J, de Borges MB, Gonçalves Pimentel MM, Santos-Rebouças CB (2017) Influence of low frequency PSEN1 variants on familial Alzheimer's disease risk in Brazil. Neurosci. Lett 653, 341345.

[34] Yeh FL, Hansen D V., Sheng M (2017) TREM2, Microglia, and Neurodegenerative Diseases. Trends Mol. Med. 23, 512-533.

[35] Vardarajan BN, Ghani M, Kahn A, Sheikh S, Sato C, Barral S, Lee JH, Cheng R, Reitz C, Lantigua R, Reyes-Dumeyer D, Medrano M, Jimenez-Velazquez IZ, Rogaeva E, St George-Hyslop P, Mayeux R (2015) Rare coding mutations identified by sequencing of Alzheimer disease genome-wide association studies loci. Ann. Neurol. 78, 487-498.

[36] Nicholson AM, Rademakers R (2016) What we know about TMEM106B in neurodegeneration. Acta Neuropathol. 132, 639-651.

[34] Yeh FL, Hansen D V., Sheng M (2017) TREM2, Microglia, and Neurodegenerative Diseases. Trends Mol. Med 23, 512-533.

[35] Colonna M, Wang Y (2016) TREM2 variants: New keys to decipher Alzheimer disease pathogenesis. Nat. Rev. Neurosci 17, 201-207. 
[36] Vardarajan BN, Ghani M, Kahn A, Sheikh S, Sato C, Barral S, Lee JH, Cheng R, Reitz C, Lantigua R, Reyes-Dumeyer D, Medrano M, Jimenez-Velazquez IZ, Rogaeva E, St George-Hyslop P, Mayeux R (2015) Rare coding mutations identified by sequencing of Alzheimer disease genome-wide association studies loci. Ann. Neurol78, 487-498.

[37] Nicholson AM, Rademakers R (2016) What we know about TMEM106B in neurodegeneration. Acta Neuropathol 132, 639-651.

[38] Van Blitterswijk M, Mullen B, Nicholson AM, Bieniek KF, Heckman MG, Baker MC, Dejesus-Hernandez M, Finch NA, Brown PH, Murray ME, Hsiung GYR, Stewart H, Karydas AM, Finger E, Kertesz A, Bigio EH, Weintraub S, Mesulam M, Hatanpaa KJ, White CL, Strong MJ, Beach TG, Wszolek ZK, Lippa C, Caselli R, Petrucelli L, Josephs KA, Parisi JE, Knopman DS, Petersen RC, Mackenzie IR, Seeley WW, Grinberg LT, Miller BL, Boylan KB, Graff-Radford NR, Boeve BF, Dickson DW, Rademakers R (2014) TMEM106B protects C9ORF72 expansion carriers against frontotemporal dementia. Acta Neuropathol 127, 397-406.

[39] Lattante S, Le Ber I, Galimberti D, Serpente M, Rivaud-Péchoux S, Camuzat A, Clot F, Fenoglio C, Scarpini E, Brice A, Kabashi E, Auriacombe S, Brice A, Blanc F, Didic M, Dubois B, Duyckaerts C, Habert MO, Golfier V, Guedj E, Hannequin D, Lacomblez L, Ber I Le, Levy R, Meininger V, Michel BF, Pasquier F, ThomasAnterion C, Puel M, Salachas F, Sellal F, Vercelletto M, Verpillat P (2014) Defining the association of TMEM106B variants among frontotemporal lobar degeneration patients with GRN mutations andC9orf72 repeat expansions. Neurobiol. Aging 35, 2658.e1-2658.e5.

[40] Lek M, Karczewski KJ, Minikel E V., Samocha KE, Banks E, Fennell T, O’DonnellLuria AH, Ware JS, Hill AJ, Cummings BB, Tukiainen T, Birnbaum DP, Kosmicki JA, 
Duncan LE, Estrada K, Zhao F, Zou J, Pierce-Hoffman E, Berghout J, Cooper DN, Deflaux N, DePristo M, Do R, Flannick J, Fromer M, Gauthier L, Goldstein J, Gupta N, Howrigan D, Kiezun A, Kurki MI, Moonshine AL, Natarajan P, Orozco L, Peloso GM, Poplin R, Rivas MA, Ruano-Rubio V, Rose SA, Ruderfer DM, Shakir K, Stenson PD, Stevens C, Thomas BP, Tiao G, Tusie-Luna MT, Weisburd B, Won HH, Yu D, Altshuler DM, Ardissino D, Boehnke M, Danesh J, Donnelly S, Elosua R, Florez JC, Gabriel SB, Getz G, Glatt SJ, Hultman CM, Kathiresan S, Laakso M, McCarroll S, McCarthy MI, McGovern D, McPherson R, Neale BM, Palotie A, Purcell SM, Saleheen D, Scharf JM, Sklar P, Sullivan PF, Tuomilehto J, Tsuang MT, Watkins HC, Wilson JG, Daly MJ, MacArthur DG (2016) Analysis of protein-coding genetic variation in 60,706 humans. Nature 536, 285-91

[41] Sequencing Initiative Suomi project (SISu), Institute for Molecular Medicine Finland (FIMM), University of Helsinki, Finland (URL: http://sisuproject.fi) [SISu v4.1] Accessed 30 August 2018 and 14 March 2019 
Table 1. Identified variants in the genes associated with the risk of EOD. 


\begin{tabular}{|c|c|c|c|c|c|c|c|c|c|c|c|}
\hline Gene & chr & $\begin{array}{l}\text { Reference } \\
\text { sequence }\end{array}$ & exon & Coding & $\begin{array}{l}\text { Protein } \\
\text { change }\end{array}$ & rs code & $\begin{array}{l}\text { Number } \\
\text { of carriers }\end{array}$ & Phenotype & $\begin{array}{l}\text { Allele frequency in } \\
\text { ExAC database } \\
\text { [40] European } \\
\text { Finnish }\end{array}$ & $\begin{array}{l}\text { Allelle } \\
\text { frequency } \\
\text { in SiSu } \\
\text { database } \\
{[41]}\end{array}$ & $\begin{array}{l}\text { Allele } \\
\text { frequency } \\
\text { in this } \\
\text { dataset }\end{array}$ \\
\hline GRN & chr17 & NM_002087 & exon11 & c.C1297T & p.Arg433Trp & rs63750412 & 4 & $\begin{array}{l}\text { AD } n=2 \\
\text { FTLD } n=2 \\
\text { FTLD+MND n=1 }\end{array}$ & 0.0366 & 0.0380747 & 0.05128 \\
\hline PSEN1 & chr14 & NM_000021 & exon9 & c.A953G & p.Glu318Gly & rs17125721 & 5 & $\begin{array}{l}\text { AD } n=2 \\
\text { FTLD } n=2 \\
\text { FTLD+MND n=1 }\end{array}$ & 0.0358 & 0.0331107 & 0.06410 \\
\hline$M A P T$ & chr17 & $\begin{array}{l}\text { NM_001123 } \\
066 \\
\text { NM_016835 }\end{array}$ & exon6 & c.A689G & p.Gln230Arg & rs63750072 & 3 & $\begin{array}{l}\text { AD } n=1 \\
\text { FTLD } n=1 \\
\text { PSP } n=1\end{array}$ & 0.03024 & 0.0266384 & 0.03846 \\
\hline$M A P T$ & chr17 & $\begin{array}{l}\text { NM_001123 } \\
066 \\
\text { NM_016835 }\end{array}$ & exon8 & c.T1321C & p.Tyr441His & rs2258689 & 22 & $\begin{array}{l}\text { AD } n=17 \\
\text { FTLD n=3 } \\
\text { FTLD+MND n=1 }\end{array}$ & 0.2895 & 0.27733 & 0.29487 \\
\hline PSEN2 & chr1 & $\begin{array}{l}\text { NM_000447 } \\
\text { NM_01248 }\end{array}$ & exon5 & c.C211T & p.Arg71Trp & rs140501902 & 1 & $\mathrm{AD} n=1$ & 0.0195 & 0.018678 & 0.012821 \\
\hline TREM2 & chr6 & $\begin{array}{l}\text { NM_001271 } \\
821 \\
\text { NM_018965 }\end{array}$ & exon2 & c. G185A & p.Arg62His & rs143332484 & 1 & $\mathrm{AD} n=1$ & 0.007893 & $\begin{array}{l}0.0075061 \\
1\end{array}$ & 0.012821 \\
\hline BIN1 & chr2 & NM_139351 & exon12 & c. $\mathrm{A} 1073 \mathrm{G}$ & p.Lys358Arg & rs138047593 & 2 & $\mathrm{AD} n=2$ & 0.01604 & 0.0137882 & 0.02564 \\
\hline
\end{tabular}




\begin{tabular}{|c|c|c|c|c|c|c|c|c|c|c|c|}
\hline UBQLN2 & $\operatorname{chr} X$ & NM_013444 & exon1 & c. T1502C & p.Ile501Thr & rs756917208 & 1 & $\mathrm{AD} n=1$ & no data & $\begin{array}{l}0.0022077 \\
5\end{array}$ & 0.012821 \\
\hline $\begin{array}{l}\text { TMEM10 } \\
6 \mathrm{~B}\end{array}$ & chr7 & $\begin{array}{l}\text { NM_001134 } \\
232\end{array}$ & exon 4 & c. G401A & p.Ser134Asn & rs147889591 & 3 & $\begin{array}{l}\mathrm{AD} n=2 \\
\text { FTLD+MND } \mathrm{n}=1\end{array}$ & 0.01482 & 0.015885 & 0.038462 \\
\hline $\begin{array}{l}\text { TMEM10 } \\
6 \mathrm{~B}\end{array}$ & chr7 & $\begin{array}{l}\text { NM_001134 } \\
232\end{array}$ & exon5 & c. $\mathrm{C} 554 \mathrm{G}$ & p.Thr185Ser & rs3173615 & 19 & $\begin{array}{l}\text { AD } n=15 \\
\text { FTLD } n=4\end{array}$ & 0.3293 & 0.319523 & 0.245359 \\
\hline APP & chr21 & $\begin{array}{l}\text { NM_000484 } \\
.3\end{array}$ & $\begin{array}{l}\text { splice } \\
\text { site, } \\
\text { intron }\end{array}$ & c. T663-7T & NA & rs183084252 & 1 & $\mathrm{AD} \mathrm{n}=1$ & 0.01164 & $\begin{array}{l}0.0094709 \\
7\end{array}$ & 0.012821 \\
\hline
\end{tabular}

ExAC=The Exome Aggregation Consortium, $\mathrm{SiSu}=$ The Sequencing Initiative Suomi, AD=Alzheimer's disease, FTLD=frontotemporal lobar degeneration, $\mathrm{MND}=$ motor neuron disease, $\mathrm{PSP}=$ progressive supranuclear paresis 
Supplementary table 1. The genes included in the targeted Neurology panel of 258 genes

\begin{tabular}{|c|c|}
\hline$A A R S$ & alanyl-tRNA synthetase \\
\hline$A B C D 1$ & $\begin{array}{l}\text { "ATP-binding cassette, sub-family D (ALD), } \\
\text { member } 1 "\end{array}$ \\
\hline$A D C K 3$ & aarF domain containing kinase 3 \\
\hline$A F G 3 L 2$ & $\begin{array}{l}\text { AFG3 ATPase family gene } 3 \text {-like } 2 \text { (S. } \\
\text { cerevisiae) }\end{array}$ \\
\hline AHII & Abelson helper integration site 1 \\
\hline$A L S 2$ & amyotrophic lateral sclerosis 2 (juvenile) \\
\hline$A M N$ & amnionless homolog (mouse) \\
\hline$A N G$ & "angiogenin, ribonuclease, RNase A family, 5" \\
\hline$A P O E$ & apolipoprotein E \\
\hline$A P P$ & amyloid beta (A4) precursor protein \\
\hline$A R$ & androgen receptor \\
\hline$A R L 13 B$ & ADP-ribosylation factor-like 13B \\
\hline$A R S A$ & arylsulfatase $\mathrm{A}$ \\
\hline$A R S B$ & arylsulfatase B \\
\hline$A R X$ & aristaless related homeobox \\
\hline$A S P A$ & aspartoacylase \\
\hline$A S P M$ & $\begin{array}{l}\text { "asp (abnormal spindle) homolog, } \\
\text { microcephaly associated (Drosophila)" }\end{array}$ \\
\hline ATL1 & atlastin GTPase 1 \\
\hline$A T M$ & ataxia telangiectasia mutated \\
\hline ATP1A3 & $\begin{array}{l}\text { "ATPase, } \mathrm{Na}+\mathrm{K}+\text { transporting, alpha } 3 \\
\text { polypeptide" }\end{array}$ \\
\hline ATP6AP2 & $\begin{array}{l}\text { "ATPase, H+ transporting, lysosomal accessory } \\
\text { protein 2" }\end{array}$ \\
\hline ATP7A & $\begin{array}{l}\text { "ATPase, } \mathrm{Cu}++ \text { transporting, alpha } \\
\text { polypeptide" }\end{array}$ \\
\hline$A T P 7 B$ & "ATPase, $\mathrm{Cu}++$ transporting, beta polypeptide" \\
\hline ATP13A2 & ATPase type $13 \mathrm{~A} 2$ \\
\hline
\end{tabular}




\begin{tabular}{|c|c|}
\hline ATXN1 & ataxin 1 \\
\hline ATXN2 & $\operatorname{ataxin} 2$ \\
\hline ATXN3 & $\operatorname{ataxin} 3$ \\
\hline ATXN7 & $\operatorname{ataxin} 7$ \\
\hline ATXN8OS & ATXN8 opposite strand (non-protein coding) \\
\hline ATXN10 & ataxin 10 \\
\hline$B C S 1 L$ & BCS1-like (S. cerevisiae) \\
\hline BIN1 & bridging integrator 1 \\
\hline CACNAIA & $\begin{array}{l}\text { "calcium channel, voltage-dependent, P/Q type, } \\
\text { alpha } 1 \text { A subunit" }\end{array}$ \\
\hline$C C 2 D 2 A$ & coiled-coil and $\mathrm{C} 2$ domain containing $2 \mathrm{~A}$ \\
\hline CCT5 & $\begin{array}{l}\text { "chaperonin containing TCP1, subunit } 5 \\
\text { (epsilon)" }\end{array}$ \\
\hline CDK5RAP2 & CDK5 regulatory subunit associated protein 2 \\
\hline$C D K L 5$ & cyclin-dependent kinase-like 5 \\
\hline CENPJ & centromere protein $\mathrm{J}$ \\
\hline CEP152 & centrosomal protein $152 \mathrm{kDa}$ \\
\hline CEP290 & centrosomal protein $290 \mathrm{kDa}$ \\
\hline CLCN1 & "chloride channel, voltage-sensitive 1" \\
\hline CLN3 & "ceroid-lipofuscinosis, neuronal 3" \\
\hline CLN5 & "ceroid-lipofuscinosis, neuronal 5" \\
\hline CLN6 & $\begin{array}{l}\text { "ceroid-lipofuscinosis, neuronal 6, late } \\
\text { infantile, variant" }\end{array}$ \\
\hline CLN8 & $\begin{array}{l}\text { "ceroid-lipofuscinosis, neuronal } 8 \text { (epilepsy, } \\
\text { progressive with mental retardation)" }\end{array}$ \\
\hline COX10 & $\begin{array}{l}\text { "COX10 homolog, cytochrome c oxidase } \\
\text { assembly protein, heme A: farnesyltransferase } \\
\text { (yeast)" }\end{array}$ \\
\hline$C T S D$ & cathepsin D \\
\hline$C Y P 7 B 1$ & $\begin{array}{l}\text { "cytochrome P450, family } 7, \text { subfamily B, } \\
\text { polypeptide } 1 "\end{array}$ \\
\hline$D L D$ & dihydrolipoamide dehydrogenase \\
\hline
\end{tabular}




\begin{tabular}{|c|c|}
\hline DNAJC5 & $\begin{array}{l}\text { "DnaJ (Hsp40) homolog, subfamily C, member } \\
\text { 5" }\end{array}$ \\
\hline DNM2 & dynamin 2 \\
\hline DRG1 & $\begin{array}{l}\text { developmentally regulated GTP binding } \\
\text { protein } 1\end{array}$ \\
\hline DYNC1H1 & "dynein, cytoplasmic 1 , heavy chain $1 "$ \\
\hline$E B P$ & emopamil binding protein (sterol isomerase) \\
\hline$E G R 2$ & early growth response 2 \\
\hline$E L N$ & elastin \\
\hline EMX2 & empty spiracles homeobox 2 \\
\hline$E P M 2 A$ & $\begin{array}{l}\text { "epilepsy, progressive myoclonus type } 2 \mathrm{~A} \text {, } \\
\text { Lafora disease (laforin)" }\end{array}$ \\
\hline ERMAP & $\begin{array}{l}\text { erythroblast membrane-associated protein } \\
\text { (Scianna blood group) }\end{array}$ \\
\hline ETHE1 & ethylmalonic encephalopathy 1 \\
\hline$F A H$ & $\begin{array}{l}\text { fumarylacetoacetate hydrolase } \\
\text { (fumarylacetoacetase) }\end{array}$ \\
\hline FGD4 & $\begin{array}{l}\text { "FYVE, RhoGEF and PH domain containing } \\
4 "\end{array}$ \\
\hline FGF14 & fibroblast growth factor 14 \\
\hline FGFRI & fibroblast growth factor receptor 1 \\
\hline FGFR2 & fibroblast growth factor receptor 2 \\
\hline FGFR3 & fibroblast growth factor receptor 3 \\
\hline FIG4 & $\begin{array}{l}\text { "FIG4 homolog, SAC1 lipid phosphatase } \\
\text { domain containing (S. cerevisiae)" }\end{array}$ \\
\hline$F L G$ & filaggrin \\
\hline FMN1 & formin 1 \\
\hline FOXH1 & forkhead box H1 \\
\hline$F O X P 2$ & forkhead box P2 \\
\hline FUS & fused in sarcoma \\
\hline$F X N$ & frataxin \\
\hline
\end{tabular}




\begin{tabular}{|c|c|}
\hline FXYD6 & $\begin{array}{l}\text { FXYD domain containing ion transport } \\
\text { regulator } 6\end{array}$ \\
\hline GALC & galactosylceramidase \\
\hline GALNS & galactosamine (N-acetyl)-6-sulfate sulfatase \\
\hline GARS & glycyl-tRNA synthetase \\
\hline GAST & gastrin \\
\hline$G B A$ & "glucosidase, beta, acid" \\
\hline GDAPI & $\begin{array}{l}\text { ganglioside induced differentiation associated } \\
\text { protein } 1\end{array}$ \\
\hline GDF6 & growth differentiation factor 6 \\
\hline GFAP & glial fibrillary acidic protein \\
\hline GJB1 & "gap junction protein, beta $1,32 \mathrm{kDa} "$ \\
\hline GJC2 & "gap junction protein, gamma 2, 47kDa" \\
\hline GLA & "galactosidase, alpha" \\
\hline GLBI & "galactosidase, beta 1" \\
\hline GLI2 & GLI family zinc finger 2 \\
\hline GNE & $\begin{array}{l}\text { glucosamine (UDP-N-acetyl)-2-epimerase/N- } \\
\text { acetylmannosamine kinase }\end{array}$ \\
\hline GNS & glucosamine (N-acetyl)-6-sulfatase \\
\hline GPR56 & G protein-coupled receptor 56 \\
\hline$G S S$ & glutathione synthetase \\
\hline GUSB & "glucuronidase, beta" \\
\hline HESX1 & HESX homeobox 1 \\
\hline$H E X B$ & hexosaminidase B (beta polypeptide) \\
\hline HGSNAT & $\begin{array}{l}\text { heparan-alpha-glucosaminide } \mathrm{N}- \\
\text { acetyltransferase }\end{array}$ \\
\hline$H L A-B$ & "major histocompatibility complex, class I, B" \\
\hline HPCA & hippocalcin \\
\hline HPRT1 & hypoxanthine phosphoribosyltransferase 1 \\
\hline$H S P B 1$ & heat shock $27 \mathrm{kDa}$ protein 1 \\
\hline HSPB8 & heat shock $22 \mathrm{kDa}$ protein 8 \\
\hline
\end{tabular}




\begin{tabular}{|c|c|}
\hline HSPDI & heat shock $60 \mathrm{kDa}$ protein 1 (chaperonin) \\
\hline HTRA2 & HtrA serine peptidase 2 \\
\hline HTT & huntingtin \\
\hline HYAL1 & hyaluronoglucosaminidase 1 \\
\hline HYLS1 & hydrolethalus syndrome 1 \\
\hline$I D S$ & iduronate 2-sulfatase \\
\hline$I D U A$ & "iduronidase, alpha-L-" \\
\hline IFRDI & interferon-related developmental regulator 1 \\
\hline$I K B K A P$ & $\begin{array}{l}\text { "inhibitor of kappa light polypeptide gene } \\
\text { enhancer in B-cells, kinase complex-associated } \\
\text { protein" }\end{array}$ \\
\hline$I K B K G$ & $\begin{array}{l}\text { "inhibitor of kappa light polypeptide gene } \\
\text { enhancer in B-cells, kinase gamma" }\end{array}$ \\
\hline INPP5E & $\begin{array}{l}\text { "inositol polyphosphate-5-phosphatase, } 72 \\
\text { kDa" }\end{array}$ \\
\hline ITPRI & "inositol 1,4,5-trisphosphate receptor, type 1" \\
\hline KCNC3 & $\begin{array}{l}\text { "potassium voltage-gated channel, Shaw- } \\
\text { related subfamily, member 3" }\end{array}$ \\
\hline KIAA0196 & KIAA0196 \\
\hline KIF1B & kinesin family member $1 \mathrm{~B}$ \\
\hline KIF5A & kinesin family member $5 \mathrm{~A}$ \\
\hline KIF7 & kinesin family member 7 \\
\hline LITAF & lipopolysaccharide-induced TNF factor \\
\hline LMNA & $\operatorname{lamin} \mathrm{A} / \mathrm{C}$ \\
\hline$L M N B 1$ & lamin B1 \\
\hline LRRK2 & leucine-rich repeat kinase 2 \\
\hline LRSAM1 & $\begin{array}{l}\text { leucine rich repeat and sterile alpha motif } \\
\text { containing } 1\end{array}$ \\
\hline$M C P H 1$ & microcephalin 1 \\
\hline$M E D 25$ & mediator complex subunit 25 \\
\hline MFN2 & mitofusin 2 \\
\hline
\end{tabular}




\begin{tabular}{|c|c|}
\hline MFSD8 & $\begin{array}{l}\text { major facilitator superfamily domain } \\
\text { containing } 8\end{array}$ \\
\hline$M P Z$ & myelin protein zero \\
\hline$M S X 2$ & msh homeobox 2 \\
\hline MTM1 & myotubularin 1 \\
\hline MTMR2 & myotubularin related protein 2 \\
\hline MYH2 & "myosin, heavy chain 2 , skeletal muscle, adult" \\
\hline$N A G A$ & "N-acetylgalactosaminidase, alpha-" \\
\hline$N A G L U$ & "N-acetylglucosaminidase, alpha" \\
\hline NAT6 & N-acetyltransferase 6 (GCN5-related) \\
\hline$N B N$ & nibrin \\
\hline NDE1 & $\begin{array}{l}\text { nudE nuclear distribution } \mathrm{E} \text { homolog } 1 \text { (A. } \\
\text { nidulans) }\end{array}$ \\
\hline NDRG1 & N-myc downstream regulated 1 \\
\hline NDUFAl & $\begin{array}{l}\text { "NADH dehydrogenase (ubiquinone) } 1 \text { alpha } \\
\text { subcomplex, } 1,7.5 \mathrm{kDa} "\end{array}$ \\
\hline NDUFAF2 & $\begin{array}{l}\text { "NADH dehydrogenase (ubiquinone) } 1 \text { alpha } \\
\text { subcomplex, assembly factor } 2 "\end{array}$ \\
\hline NDUFS1 & $\begin{array}{l}\text { "NADH dehydrogenase (ubiquinone) Fe-S } \\
\text { protein } 1,75 \mathrm{kDa}(\mathrm{NADH} \text {-coenzyme Q } \\
\text { reductase)" }\end{array}$ \\
\hline NDUFS4 & $\begin{array}{l}\text { "NADH dehydrogenase (ubiquinone) Fe-S } \\
\text { protein } 4,18 \mathrm{kDa}(\mathrm{NADH} \text {-coenzyme Q } \\
\text { reductase)" }\end{array}$ \\
\hline NDUFS7 & $\begin{array}{l}\text { "NADH dehydrogenase (ubiquinone) Fe-S } \\
\text { protein } 7,20 \mathrm{kDa}(\mathrm{NADH} \text {-coenzyme Q } \\
\text { reductase)" }\end{array}$ \\
\hline NDUFS8 & $\begin{array}{l}\text { "NADH dehydrogenase (ubiquinone) Fe-S } \\
\text { protein } 8,23 \mathrm{kDa} \text { (NADH-coenzyme Q } \\
\text { reductase)" }\end{array}$ \\
\hline NDUFV1 & $\begin{array}{l}\text { "NADH dehydrogenase (ubiquinone) } \\
\text { flavoprotein } 1,51 \mathrm{kDa}\end{array}$ \\
\hline$N E F L$ & "neurofilament, light polypeptide" \\
\hline NF1 & neurofibromin 1 \\
\hline
\end{tabular}




\begin{tabular}{|c|c|}
\hline NF2 & neurofibromin 2 (merlin) \\
\hline NHLRC1 & NHL repeat containing 1 \\
\hline NIPAl & $\begin{array}{l}\text { non imprinted in Prader-Willi/Angelman } \\
\text { syndrome } 1\end{array}$ \\
\hline NLGN3 & neuroligin 3 \\
\hline NLGN4X & "neuroligin 4, X-linked" \\
\hline NODAL & nodal homolog (mouse) \\
\hline NPC1 & "Niemann-Pick disease, type C1" \\
\hline NPC2 & "Niemann-Pick disease, type C2" \\
\hline NPHPl & nephronophthisis 1 (juvenile) \\
\hline NR4A2 & $\begin{array}{l}\text { "nuclear receptor subfamily 4, group A, } \\
\text { member 2" }\end{array}$ \\
\hline NSD1 & nuclear receptor binding SET domain protein 1 \\
\hline OFD1 & oral-facial-digital syndrome 1 \\
\hline OPTN & optineurin \\
\hline PARK2 & $\begin{array}{l}\text { "parkinson protein 2, E3 ubiquitin protein } \\
\text { ligase (parkin)" }\end{array}$ \\
\hline PARK7 & parkinson protein 7 \\
\hline PDHAI & pyruvate dehydrogenase (lipoamide) alpha 1 \\
\hline$P D Y N$ & prodynorphin \\
\hline$P E X 7$ & peroxisomal biogenesis factor 7 \\
\hline PHYH & phytanoyl-CoA 2-hydroxylase \\
\hline PINK1 & PTEN induced putative kinase 1 \\
\hline$P M E L$ & premelanosome protein \\
\hline PMPCA & peptidase (mitochondrial processing) alpha \\
\hline PNPLA6 & patatin-like phospholipase domain containing 6 \\
\hline$P O L G$ & "polymerase (DNA directed), gamma" \\
\hline$P P P 2 R 2 B$ & $\begin{array}{l}\text { "protein phosphatase } 2 \text {, regulatory subunit B, } \\
\text { beta" }\end{array}$ \\
\hline$P P T 1$ & palmitoyl-protein thioesterase 1 \\
\hline$P Q B P 1$ & polyglutamine binding protein 1 \\
\hline
\end{tabular}




\begin{tabular}{|c|c|}
\hline$P R K C G$ & "protein kinase $\mathrm{C}$, gamma" \\
\hline PRKRA & $\begin{array}{l}\text { "protein kinase, interferon-inducible double } \\
\text { stranded RNA dependent activator" }\end{array}$ \\
\hline PRNP & prion protein \\
\hline PRODH & proline dehydrogenase (oxidase) 1 \\
\hline PRODH 2 & proline dehydrogenase (oxidase) 2 \\
\hline PRPS1 & phosphoribosyl pyrophosphate synthetase 1 \\
\hline$P R X$ & periaxin \\
\hline PSAP & prosaposin \\
\hline PSEN1 & presenilin 1 \\
\hline PSEN2 & presenilin 2 (Alzheimer disease 4) \\
\hline PTCHI & patched 1 \\
\hline$R A B 7 A$ & "RAB7A, member RAS oncogene family" \\
\hline$R A X$ & retina and anterior neural fold homeobox \\
\hline REEP1 & receptor accessory protein 1 \\
\hline RELN & reelin \\
\hline RPGRIPIL & RPGRIP1-like \\
\hline RPS6KA3 & $\begin{array}{l}\text { "ribosomal protein S6 kinase, 90kDa, } \\
\text { polypeptide 3" }\end{array}$ \\
\hline$S B F 2$ & SET binding factor 2 \\
\hline SCO1 & $\begin{array}{l}\text { SCO cytochrome oxidase deficient homolog } 1 \\
\text { (yeast) }\end{array}$ \\
\hline $\mathrm{SCO} 2$ & $\begin{array}{l}\text { SCO cytochrome oxidase deficient homolog } 2 \\
\text { (yeast) }\end{array}$ \\
\hline SDHA & $\begin{array}{l}\text { "succinate dehydrogenase complex, subunit } \mathrm{A} \text {, } \\
\text { flavoprotein }(\mathrm{Fp}) \text { " }\end{array}$ \\
\hline 9-Sep & septin 9 \\
\hline SETX & senataxin \\
\hline SGCE & "sarcoglycan, epsilon" \\
\hline SGSH & $\mathrm{N}$-sulfoglucosamine sulfohydrolase \\
\hline SH3TC2 & SH3 domain and tetratricopeptide repeats 2 \\
\hline
\end{tabular}




\begin{tabular}{|c|c|}
\hline SHH & sonic hedgehog \\
\hline SIX3 & SIX homeobox 3 \\
\hline$S L C 2 A 1$ & $\begin{array}{l}\text { "solute carrier family } 2 \text { (facilitated glucose } \\
\text { transporter), member } 1 \text { " }\end{array}$ \\
\hline SLC6A4 & $\begin{array}{l}\text { "solute carrier family } 6 \text { (neurotransmitter } \\
\text { transporter, serotonin), member 4" }\end{array}$ \\
\hline SLC12A6 & $\begin{array}{l}\text { "solute carrier family } 12 \text { (potassium/chloride } \\
\text { transporters), member } 6 \text { " }\end{array}$ \\
\hline$S L C 33 A 1$ & $\begin{array}{l}\text { "solute carrier family } 33 \text { (acetyl-CoA } \\
\text { transporter), member } 1 "\end{array}$ \\
\hline SLITRK1 & "SLIT and NTRK-like family, member 1" \\
\hline SMADI & SMAD family member 1 \\
\hline SMN1 & "survival of motor neuron 1 , telomeric" \\
\hline SMN2 & "survival of motor neuron 2 , centromeric" \\
\hline SNCA & $\begin{array}{l}\text { "synuclein, alpha (non A4 component of } \\
\text { amyloid precursor)" }\end{array}$ \\
\hline SNCAIP & "synuclein, alpha interacting protein" \\
\hline SNRPN & small nuclear ribonucleoprotein polypeptide $\mathrm{N}$ \\
\hline SOD1 & "superoxide dismutase 1 , soluble" \\
\hline SP110 & SP110 nuclear body protein \\
\hline SPAST & spastin \\
\hline$S P G 7$ & $\begin{array}{l}\text { spastic paraplegia } 7 \text { (pure and complicated } \\
\text { autosomal recessive) }\end{array}$ \\
\hline SPG11 & spastic paraplegia 11 (autosomal recessive) \\
\hline$S P G 20$ & spastic paraplegia 20 (Troyer syndrome) \\
\hline SPG21 & $\begin{array}{l}\text { "spastic paraplegia } 21 \text { (autosomal recessive, } \\
\text { Mast syndrome)" }\end{array}$ \\
\hline SPRED1 & "sprouty-related, EVH1 domain containing 1" \\
\hline SPTBN2 & "spectrin, beta, non-erythrocytic 2" \\
\hline STIL & SCL/TAL1 interrupting locus \\
\hline STXBP1 & syntaxin binding protein 1 \\
\hline SURF1 & surfeit 1 \\
\hline
\end{tabular}




\begin{tabular}{|c|c|}
\hline SYNE1 & $\begin{array}{l}\text { "spectrin repeat containing, nuclear envelope } \\
1 "\end{array}$ \\
\hline TAAR6 & trace amine associated receptor 6 \\
\hline$T A R D B P$ & TAR DNA binding protein \\
\hline$T B P$ & TATA box binding protein \\
\hline TCTN1 & tectonic family member 1 \\
\hline TCTN2 & tectonic family member 2 \\
\hline$T D P 1$ & tyrosyl-DNA phosphodiesterase 1 \\
\hline TGFB1 & "transforming growth factor, beta 1" \\
\hline TGIF1 & TGFB-induced factor homeobox 1 \\
\hline THAPl & $\begin{array}{l}\text { "THAP domain containing, apoptosis } \\
\text { associated protein } 1 "\end{array}$ \\
\hline TIMM8A & $\begin{array}{l}\text { translocase of inner mitochondrial membrane } 8 \\
\text { homolog A (yeast) }\end{array}$ \\
\hline TMEM67 & transmembrane protein 67 \\
\hline TMEM216 & transmembrane protein 216 \\
\hline TORIA & "torsin family 1, member A (torsin A)" \\
\hline$T P P 1$ & tripeptidyl peptidase I \\
\hline TRPV4 & $\begin{array}{l}\text { "transient receptor potential cation channel, } \\
\text { subfamily V, member } 4 "\end{array}$ \\
\hline TSC1 & tuberous sclerosis 1 \\
\hline$T S C 2$ & tuberous sclerosis 2 \\
\hline TTBK2 & tau tubulin kinase 2 \\
\hline$T T P A$ & tocopherol (alpha) transfer protein \\
\hline TUBAIA & "tubulin, alpha 1a" \\
\hline TWIST1 & twist homolog 1 (Drosophila) \\
\hline$U B E 3 A$ & ubiquitin protein ligase E3A \\
\hline UCHL1 & $\begin{array}{l}\text { ubiquitin carboxyl-terminal esterase L1 } \\
\text { (ubiquitin thiolesterase) }\end{array}$ \\
\hline VANGL1 & "vang-like 1 (van gogh, Drosophila)" \\
\hline$V A P B$ & $\begin{array}{l}\text { VAMP (vesicle-associated membrane protein)- } \\
\text { associated protein B and C }\end{array}$ \\
\hline
\end{tabular}




\begin{tabular}{|l|l|}
\hline VCP & valosin containing protein \\
\hline WDR62 & WD repeat domain 62 \\
\hline ZFYVE26 & "zinc finger, FYVE domain containing 26" \\
\hline ZFYVE27 & "zinc finger, FYVE domain containing 27" \\
\hline ZIC2 & Zic family member 2 \\
\hline
\end{tabular}


Supplementary table 2. The additional genes included in the analyse

\begin{tabular}{|l|l|}
\hline Chromosome & Start position \\
\hline \hline APP, chr21 & $\underline{27252861-27543138}$ \\
\hline PSEN1, chr14 & $\underline{73603525-73690399}$ \\
\hline PSEN2, chr1 & $\underline{227058273-227083804}$ \\
\hline MAPT, chr17 & $\underline{762281-895830}$ \\
\hline GRN, chr17 & $\underline{42422491-42430470}$ \\
\hline VCP, chr9 & $\underline{35057373-35071974}$ \\
\hline CHMP2B, chr3 & $\underline{87276413-87304698}$ \\
\hline FUS, chr16 & $\underline{31191431-31194671}$ \\
\hline TARDBP, chr1 & $\underline{11072679-11085549}$ \\
\hline TREM2, chr6 & $\underline{41126246-41130922}$ \\
\hline TMEM106B, chr7 & $\underline{12250848-12276890}$ \\
\hline SNCA, chr4 & $\underline{90743397-90758348}$ \\
\hline PARK2, chr6 & $\underline{161768590-163148834}$ \\
\hline PARK7, chr1 & $\underline{8021714-8045342}$ \\
\hline LRRK2, chr12 & $\underline{40689229-40763086}$ \\
\hline PINK1, chr1 & $\underline{20972001-20978004}$ \\
\hline CSF1R, chr5 & $\underline{149456467-149466170}$ \\
\hline PRNP, chr20 & $\underline{4679867-4680628}$ \\
\hline UBQLN2, chrX & $\underline{56590060-56592380}$ \\
\hline Profilin1, chr17 & $\underline{4848947-4851825}$ \\
\hline SOD1, chr21 & $\underline{3631935-33041243}$ \\
\hline UBQLN1, chr9 & \\
\hline
\end{tabular}

